\title{
O QUE DIRIA HANNAH ARENDT SOBRE O CENTENÁRIO DA REVOLUÇÃO RUSSA ${ }^{1}$ \\ José Luiz de Oliveira (UFSJ) $)^{2}$ \\ jlos@ufsj.edu.br
}

Resumo: Ao tratar da ação do homem contemporâneo no que diz respeito à Revolução Russa, Hannah Arendt elabora abordagens no campo da filosofia política. Trata-se de abordagens que, certamente, podem iluminar o tempo presente, principalmente quando comemoramos o centenário dessa importante ruptura ocorrida em 1917. A autora, em suas análises, procura demonstrar que as experiências dos conselhos na Rússia, configurados em Sovietes, se fortaleceram a partir dos movimentos de 1905 por meio de ondas de greves espontâneas. Arendt faz referência ao caráter republicano dos Sovietes. Ou seja, havia um ideal de fundação de uma república baseada na estrutura organizacional dos Sovietes, traduzidos em espaços de liberdade. A movimentação dos Sovietes e do Partido Bolchevique culminou com a tomada do poder. Os rumos assumidos pelo governo de Lênin abriram precedentes para o desenvolvimento posterior quando o Partido, com toda a sua máquina, se tornaria onipotente. Com a ascensão de Stalin ao poder, instaurou-se o domínio total. Isto é, o totalitarismo alcançou o seu clímax com a perseguição e destruição daqueles que foram considerados inimigos objetivos e com a criação de campos de concentração. Com a ascensão de Nikita Khrushchev ao poder, iniciaram-se alguns sinais de destotalitarização da União Soviética.

Palavras-chave: Centenário; liberdade; revolução; Sovietes.

\footnotetext{
${ }^{1}$ Recebido: 28-07-2018/Aceito: 01-08-2018/ Publicado on-line: 07-08-2018.

${ }^{2}$ José Luiz de Oliveira é Professor associado do Departamento de Filosofia e Métodos da Universidade Federal de São João del-Rei, São João del-Rei, MG, Brasil.
} 


\section{INTRODUÇÃO}

Hannah Arendt (2011, p. 35), ao iniciar as suas abordagens acerca da relação entre guerras e revoluções, faz menção ao líder da Revolução Russa de 1917 da seguinte maneira: "Guerras e revoluções - como se os acontecimentos apenas se apressassem em cumprir a previsão inicial de Lênin têm determinado até hoje a fisionomia do século XX". Embora Arendt (2011), em sua obra Sobre a Revolução, trate muito mais das Revoluções Francesa e Americana, há também alusões em torno da Revolução Russa de 1917. Ao se referir a Lênin, Arendt demonstra que tanto ele quanto os acontecimentos de cem anos atrás possuem relevância para a história da filosofia política contemporânea.

Embora faça menções aos acontecimentos de 1905 na Rússia, Arendt, quando faz referências à Revolução Russa, está se dirigindo aos acontecimentos de 1917, marcados pela subida de Lênin ao poder e por todas as suas tentativas de fortalecimento de políticas de desenvolvimento social e econômica, a exemplo da Nova Política Econômica (NEP). A ascensão de Stalin ao poder, bem como os seus esforços de consolidação do domínio total, podem ser considerados o momento que marca o fim de todas as pretensões assumidas pelos Sovietes, que culminaram nos acontecimentos de outubro de 1917, particularmente se considerarmos o quanto o fim dos Sovietes representou enquanto aniquilação dos anseios de fundação da liberdade política tal como essas organizações pleiteavam.

As revoluções, para Arendt, constituem a fundação na História. Referir-se ao tema da fundação, no caso da Revolução Russa de 1917, é voltar-se para a experiência dos con- 
selhos. Em suas análises, Arendt procura demonstrar que as experiências dos conselhos na Rússia, configurados em Sovietes, se fortaleceram a partir dos movimentos de 1905. Os Sovietes, na perspectiva arendtiana, são concebidos como o elemento principal que registrou os espaços de liberdade, os quais pulsaram no seio da Rússia revolucionária. No primeiro item deste nosso trabalho, trataremos do ideal de fundação republicana presente nos Sovietes $^{3}$ admitido por Arendt.

No segundo item, explicitaremos que, uma vez estando à frente do governo, Lênin foi gradativamente assumindo o controle do poder amparado nas ações do Partido Bolchevique em detrimento dos Sovietes. O pragmatismo do principal líder da Revolução foi permitindo a abertura do caminho para que os princípios dos Sovietes fossem eliminados progressivamente.

No terceiro momento de nossa abordagem, demonstraremos que, por meio da ascensão de Stalin ao poder, instaurou-se o domínio total; isto é, o totalitarismo alcançou o seu clímax com a perseguição e destruição daqueles que foram considerados inimigos objetivos. As constantes investidas de Stalin foram inicialmente direcionadas aos Sovietes, passando por todas as classes sociais até culminar com a

\footnotetext{
${ }^{3}$ Arendt (2011, p. 331) adverte que havia uma concepção republicana nos Sovietes, ao dizer: "Os Conselhos, claro, eram espaços de liberdade. Como tais, invariavelmente não aceitavam ser considerados órgãos temporários da revolução e, muito pelo contrário, se empenhavam ao máximo para se estabelecer como órgãos permanentes do governo. Longe de querer tornar a revolução permanente, o objetivo explícito deles era 'lançar as fundações de uma república proclamada com todas as suas consequências, o único governo que encerrará para sempre a era das invasões e guerras civis'; não o paraíso na Terra, não uma sociedade sem classes, não o sonho da fraternidade socialista ou comunista, mas a instauração da 'verdadeira república': tal era a 'recompensa' que se esperava como fim da luta".
} 
destruição de todas as forças opositoras ao regime presentes nas estruturas internas do Partido e no seio da burocracia do Estado.

Enfim, mostraremos de que maneira Arendt admite que a União Soviética passou a apresentar sinais de destotalitarização após a morte de Stalin com a consequente ascensão de Nikita Khrushchev ao poder.

\section{O IDEAL DE FUNDAÇÃO PRESENTE NOS SOVIETES}

Ao abordar uma das mais relevantes ações humanas no que tange às movimentações que culminaram na eclosão da Revolução Russa, Arendt expõe parte de suas contribuições para o processo que envolve a história da filosofia contemporânea. A atuação intelectual dessa pensadora se realiza por meio de abordagens de temas recorrentes ao campo da filosofia política. São análises que ocorrem na esfera de importantes acontecimentos políticos, longe das especulações de caráter metafísico. A atenção às novidades ocorridas no seio do mundo, especialmente no que diz respeito aos acontecimentos políticos do século XX, revela o quanto Arendt (2011, p. 10) mantém coerência com a afirmação de que, "como a ação é a atividade política por excelência, a natalidade, e não a mortalidade, pode ser a categoria central do pensamento político em contraposição ao pensamento metafísico”. Nessa perspectiva, a filosofia política da nossa pensadora apresenta uma relação da ação com a categoria da natalidade. Todo recém-chegado ao mundo possui a capacidade de iniciar algo novo, o que, para Arendt, significa agir. Desse modo, todas as atividades humanas estão estreitamente ligadas à condição humana da natalidade. 
Em suas análises acerca da Revolução Russa, Arendt (2011, p. 321-322) chama-nos a atenção para o surgimento na Rússia de uma nova forma de governo. Para a pensadora, essa nova forma de governo guardava certa semelhança com o sistema distrital da América admitido por Jefferson. Essa novidade de células políticas vivida na Rússia parecia, aos olhos da autora, repetir, em todas as suas circunstâncias, as sociedades revolucionárias, bem como os conselhos municipais que haviam se alastrado por todo o território francês após os acontecimentos de 1789. Dito em outras palavras, o fenômeno dos Sovietes, uma experiência ocorrida na Rússia, possuía várias semelhanças com os distritos de Jefferson, as sociedades e os conselhos municipais da França. O surgimento de conselhos nos séculos XIX e XX foi uma novidade que chamou a atenção de alguns líderes. Isto é, o advento dos conselhos foi um fenômeno que, segundo Arendt, teria impressionado os dois maiores líderes revolucionários do período pós-Revolução Francesa: no século XIX, Marx, durante a Comuna de Paris, e no início do século XX, Lênin, durante a eclosão da primeira Revolução Russa de 1905. Ambos vivenciaram experiências em torno de um movimento político de caráter espontâneo em momentos históricos diferentes. No caso de Marx, foram as comunas e, no caso de Lênin, o aparecimento dos Sovietes que surgiram antes da eclosão revolucionária de 1917 e, por sua vez, eram tipos de conselhos que, na sua versão russa, possuíam a pretensão de sobreviver à Revolução.

Arendt (2011, p. 323) enfatiza que, em 1905 e em 1917, Lênin ficou impactado pelos acontecimentos revolucionários a ponto de elogiar "a criatividade revolucionária do povo”. Essa impressão do líder revolucionário amparava- 
se na concepção de que o povo havia começado de maneira espontânea uma estrutura de poder inteiramente nova. Ou seja, havia uma estrutura organizacional, apresentada no curso da Revolução, nunca antes vista pela população russa. Essa novidade de organização política foi tão marcante que culminou com a adoção do lema da Revolução de outubro de 1917: "Todo o poder aos Sovietes". A novidade dos Sovietes era alarmante, uma vez que teria apanhado Lênin e o Partido Bolchevique de surpresa. Os Sovietes, órgãos de organização elementar, típicos da Rússia da primeira metade do século $\mathrm{XX}$, se apresentaram na condição de registro de um tipo de ação política caracterizada pela espontaneidade que, de certa maneira, se traduz na concepção arendtiana de fundação. Essa espontaneidade anunciada por Arendt (2011, p. 313) se estabelece considerando que os conselhos, incluindo a versão em Sovietes, "sempre que apareciam, eles brotavam como órgãos espontâneos do povo não só fora de todos os partidos revolucionários, mas também de maneira inesperada para eles e seus dirigentes". Desse modo, o caráter espontâneo se faz devido ao fato de os diversos conselhos não aparecerem no interior dos partidos e surgirem de surpresa, escapando dos olhos de seus dirigentes. Assim como o despontar espontâneo dos conselhos se constitui pelo surgimento do novo, o processo de fundação no âmbito de uma revolução ocorre da mesma forma, pois, para Arendt (2011, p. 46), "as revoluções são os únicos eventos políticos que nos colocam diante do problema dos inícios de uma maneira frontal e inescapável".

Para os nossos propósitos, é relevante se referir à tópica da fundação em Arendt, já que, ao tratar do fenômeno revolucionário, inclusive a Revolução Russa, a pensadora se 
volta para o tema da fundação. Em termos arendtianos, a fundação é um fenômeno que pode ser registrado desde as narrativas lendárias da Antiguidade. Arendt (2011, p. 166), em suas análises sobre a História romana, considera que esta sempre esteve alicerçada na ideia da fundação e que nenhuma das grandes concepções políticas romanas - tais como o tripé Autoridade, Tradição e Religião, bem como a ideia de Lex - poderia ser entendida sem uma compreensão acerca do grande feito que marca o início da História e da cronologia romana, o feito da Urbs Condita, que se traduz na fundação da cidade eterna.

Arendt (1992, p. 162) também adverte que a cidade de Roma é um exemplo de fundação que acontece no contexto da Antiguidade. A partir desse contexto, Arendt dá uma atenção considerável à fundação, pois, para ela, no âmbito da História romana, a fundação era algo que se processava no âmago da política assumida por Roma, que se instalou desde o início da República até o fim da era imperial. Conforme os romanos, o caráter sagrado da fundação permitia que aquilo que fosse fundado permanecesse para todas as gerações futuras. Nesse sentido, ao participar da política, o cidadão romano estaria preservando a fundação da cidade de Roma. Portanto, ampliar o Império Romano significava, antes de tudo, repetir a fundação de Roma. Todavia, a ideia de fundação não é uma tópica que diz respeito somente à Antiguidade. O problema da fundação é uma questão a ser tratada por toda a História do pensamento político ocidental, porque ela é uma tópica que sempre esteve presente na origem dos corpos políticos em todos os momentos da História política ocidental.

Nesse sentido, a fundação no contexto das investigações 
referentes à História da Filosofia Política Moderna e Contemporânea tem na Revolução a sua própria expressão, que, por si só, se constitui como a própria instauração do novo. Isso quer dizer que a própria instauração do evento revolucionário já é uma novidade em si mesma. Ou seja, a falta de outro evento que o precedesse fez dele uma novidade relevante. A novidade aqui tem como um de seus aspectos a própria ausência de precedência. Entretanto, essa ausência de precedência histórica é compreendida dentro dos aspectos que compõem o elemento novidade. Dessa maneira, percebemos que Arendt trata da revolução concebendo-a como o início de um novo rumo na História.

Em termos arendtianos, esse novo rumo ocorre de uma maneira na qual os agentes ou os filhos da Revolução passam a perder o controle desse rumo. $\mathrm{O}$ fenômeno revolucionário apresenta-se na forma de acontecimentos que caminham numa direção que se projeta para muito além daquilo que pode se considerar como acontecimentos que se apresentam como meras mudanças. Referindo-se aos acontecimentos iniciais da Revolução Francesa, Arendt (2011, p.78-79) nos lembra que a prova de que a Revolução não significou uma mera mudança reside no famoso diálogo travado entre o rei Luís XVI com o duque de La Rochefoucauld-Liancourt. Trata-se de um diálogo cujo núcleo é a notícia acerca da queda da Bastilha e a consequente libertação de uns poucos prisioneiros, e da defecção das tropas reais frente a um ataque popular. Arendt adverte que esse diálogo entre o rei e o seu mensageiro tornou-se famoso e de caráter lacônico e revelador. Nessa ocasião, o rei teria exclamado que os fatos ocorridos na noite de 14 de julho de 1789, em Paris, teriam sido uma revolta - "C'est une révolt". 
Logo em seguida, o seu mensageiro Liancourt o corrigiu afirmando que aquele célebre acontecimento não se tratava de uma revolta - "Non, sire, c'est une revolution". Em termos da interpretação arendtiana, esse diálogo aponta o sentido político de um movimento dotado de irresistibilidade.

Nesse sentido, aponta Arendt (2011, p. 79) que o movimento agora passa a ser visto como algo incapaz de ser detido, pois Liancourt replicou que o que havia acontecido tratava-se de uma situação de caráter irrevogável e capaz de ir além do poder de um monarca. Comparado àquilo que antes era compreendido como uma revolta controlável, a partir daquele momento tratava-se de uma Revolução que, enquanto ação fundadora se apresentava demonstrando a sua característica de um evento marcado pela irrevogabilidade ou pela irreversibilidade. Trata-se de ter que lidar com o caráter irrevogável e irreversível da ação. Por essa razão, lembra Arendt (2011, p. 80) que "a noção de um movimento irreversível, que o século XX logo iria conceitualizar na ideia de necessidade histórica, ressoa em todas as páginas da Revolução Francesa, do começo ao fim”. O sentido de revolução passou a ser compreendido como força avassaladora e incapaz de ser detida até mesmo pelos seus próprios agentes. Destarte, anuncia Arendt (2011, p. 80): "É a majestosa corrente da lava da revolução que não poupa nada e ninguém pode deter', como testemunhou Georg Forster em 1793; é o espetáculo que recai sob o signo de Saturno: 'A revolução devorando os próprios filhos', como colocou Vergniaud, o grande orador da Gironda”.

O conceito de fundação em Arendt se faz por meio da demonstração do quanto o homem é um ser livre e, consequentemente, capaz de mudar o curso dos acontecimentos. 
O entendimento de fundação em Arendt se baseia na aposta de que a capacidade de começar algo inteiramente novo é uma característica tipicamente dos seres humanos. Nessa perspectiva, todos os tipos de conselhos, incluindo os Sovietes, se constituem como espaços potencialmente dotados de condições capazes de desencadear o processo revolucionário, deixando, então, visível a concretização do potencial fundador.

A novidade trazida pela experiência dos Sovietes era a de que se tratava de conselhos que reforçavam a concepção de abertura de espaço público enquanto instâncias que valorizavam movimentos espontâneos. É por esse motivo que Arendt (2011, p. 328), em suas análises, procura demonstrar que as experiências dos Sovietes na Rússia se fortaleceram a partir dos movimentos de 1905 por meio de ondas de greves espontâneas. Essa espontaneidade se firmou fora dos grupos e partidos revolucionários. Pode-se dizer que os Sovietes representavam a versão russa dos conselhos e, para Arendt (2011, p. 331), "os conselhos, claro, eram espaços de liberdade”. É importante enfatizar que liberdade, na visão de Arendt (1992, p. 195), só é possível existir quando se estabelece um domínio público ${ }^{4}$ para que ela possa se manifestar; isto é: "Sem um âmbito politicamente assegurado, falta à liberdade o espaço concreto onde aparecer".

Nessa perspectiva, tanto o exercício da liberdade quan-

\footnotetext{
${ }^{4}$ A concepção arendtiana de liberdade política difere da chamada liberdade interior, na qual não é possível lidar com fatos demonstráveis. A esse respeito, diz Arendt (1992, p. 195): "Ela pode, certamente, habitar ainda nos corações dos homens como desejo, vontade, esperança ou anelo; mas o coração humano, como todos o sabemos, é um lugar muito sombrio, e qualquer coisa que vá para sua obscuridade não pode ser chamada adequadamente de um fato demonstrável. A liberdade como fato demonstrável e a política coincidem e são relacionadas uma à outra como dois lados da mesma matéria".
} 
to a ação política requerem um espaço onde elas possam aparecer. A manifestação da liberdade constitui ponto nodal para o entendimento do conceito arendtiano de ação. Daí a insistência de Arendt (1992, p. 192) ao afirmar: "Sem ela, a vida política como tal seria destituída de significado. A raison d'être da política é a liberdade, e seu domínio de experiência é a ação". Se os conselhos, aos olhos de Arendt, eram espaços de liberdade, no interior deles se efetivava o fato demonstrável da política e da liberdade. É na manifestação conjunta entre liberdade e política que encontramos o motivo central que justifica a existência da coincidência entre ambas. Depreendemos, então, que a manifestação da política que ocorre por meio da efetivação da ação em espaços públicos somente pode se concretizar mediante o estabelecimento de canais de liberdade. Isto é, os problemas alicerçados no encaminhamento da política e da ação dependem da existência da liberdade. A esse respeito, salienta Arendt:

E mesmo hoje em dia, quer o saibamos ou não, devemos ter sempre em mente, ao falarmos do problema da liberdade, o problema da política e o fato de o homem ser dotado com o dom da ação; pois ação e política, entre todas as capacidades e potencialidades da vida humana, são as únicas coisas que não poderíamos sequer conceber sem ao menos admitir a existência da liberdade, e é difícil tocar em um problema político particular sem, implícita ou explicitamente, tocar em um problema de liberdade humana (ARENDT, 1992, p. 191192).

Dessa maneira, ação, política e liberdade são conceitos que se encontram intimamente relacionados entre si e, consequentemente, contribuem para esclarecer a definição arendtiana de revolução. A liberdade, tal como Hannah 
Arendt a concebe, encontra-se definitivamente apoiada em conceitos contrários aos princípios que fundamentam a ordem estabelecida pela política de atuação dos regimes totalitários. Conforme Arendt (1992, p. 191), "o campo em que a liberdade sempre foi conhecida, não como um problema é claro, mas como um fato da vida cotidiana, é o âmbito da política”. A pensadora admite, assim, ser a liberdade a condição necessária para que haja à política o seu significado preciso. Desse ponto de vista, a liberdade só existe quando unida à dimensão política da existência humana. Por causa disso, passa também a se colocar como a razão de ser da política. Numa de suas conferências, intitulada "Será que a política ainda tem algum sentido?”, Arendt (1993, p. 117) salientou que "[...] para a questão referente ao sentido da política, há uma resposta tão simples e conclusiva em si mesma, que se poderia pensar que as outras respostas são totalmente desnecessárias”. Segundo ela, a resposta é a seguinte: "o sentido da política é a liberdade". Por essa afirmação, percebemos que, no processo de desenvolvimento de sua filosofia política, Hannah Arendt articula estreitamente as temáticas da liberdade e da política ${ }^{5}$.

A novidade dos Sovietes, ou seja, a falta de precedência desses tipos de conselhos na história da Rússia, é realçada

\footnotetext{
${ }^{5}$ Podemos afirmar que a concepção arendtiana da liberdade caracteriza-a como a categoria que irá estabelecer os vínculos entre seu apelo à tradição e sua crítica aos modelos impostos pela experiência do totalitarismo. Essa liberdade política, vista da perspectiva arendtiana, se manifesta no agir concreto, ou seja, no mundo público, em contraposição ao sentido da liberdade da interioridade, que aparece fora da dinâmica do mundo da política. A esse propósito, observa Arendt (1992, p. 192): "A liberdade que admitimos como instaurada em toda teoria política e que mesmo os que louvam a tirania precisam levar em conta é o próprio oposto da 'liberdade interior', o espaço íntimo no qual os homens podem fugir à coerção externa e sentir-se livres. Esse sentir interior permanece sem manifestações externas e é, portanto, por definição, sem significação política".
} 
por Arendt, porque, de acordo com ela:

Desde as revoluções do século dezoito, todo grande levante desenvolveu realmente os rudimentos de uma forma completamente nova de governo, que surgiu, independente de todas as teorias revolucionárias precedentes, diretamente fora do curso da revolução em si, isto é, fora das experiências de ação e fora do desejo resultante dos atores em participar do ulterior desenvolvimento dos assuntos públicos (ARENDT, 2004, p. 199).

É importante destacar que a novidade dos conselhos russos, ou Sovietes, é lembrada por Arendt no sentido de que se trata de um tipo de organização que não fazia parte das pretensões dos teóricos das revoluções. Não havia experiências de ação na história da Rússia que pudessem se assemelhar aos conselhos, principalmente quando consideramos que é da natureza política dos conselhos que eles sejam dotados de estruturas elementares de poder. Os conselhos, aos quais Arendt se refere, possuem estrutura organizacional de caráter horizontal; isto é, no seu interior as deliberações nascem e se articulam de baixo para cima.

No entendimento de Arendt (2011, p. 331), no seio da sociedade russa que se encontrava em ebulição revolucionária, o que esses conselhos propunham era jamais serem considerados como órgãos temporários da Revolução. Por essa razão, empenhavam-se bastante para que pudessem se estabelecer como órgãos permanentes do governo revolucionário. Destaca Arendt (2011, p. 331) que os conselhos russos pleiteavam explicitamente "lançar as fundações de uma república proclamada com todas as suas consequências, o único governo que encerrará para sempre a era das invasões e guerras civis". Dessa maneira, os conselhos pleiteavam a instauração de um governo com características re- 
publicanas e que fosse capaz de promover a paz.

Naquele contexto, no qual se buscava tomar o poder político institucional na Rússia, Arendt (2011, p. 331) realça que os membros dos Sovietes não estavam interessados em estabelecer um governo que criasse um paraíso na Terra, sociedade desprovida de classes, bem como o sonho pautado na fraternidade de cunho socialista e comunista. $\mathrm{O}$ que eles pretendiam instaurar de fato era "a verdadeira república”. Em outras palavras, o que os membros dos Sovietes almejavam era a fundação de uma república com bases nos movimentos populares espontâneos, que viria como um tipo de "recompensa" com o objetivo de coroar o fim da luta. Semelhantemente ao que havia acontecido na Comuna de Paris em 1871, a fundação de uma república também era a intenção dos membros dos Sovietes, que outrora brotaram em solo russo. Muitos testemunharam as lutas dos membros dos conselhos e, por isso, acreditavam e sentiam que esses órgãos poderiam provocar o surgimento e a formação de uma força, que um dia poderia ser capaz de alcançar efetivamente a transformação do Estado. Arendt busca demonstrar que os Sovietes, no que tange à capacidade que eles possuíam de transformação do Estado, se assemelhavam aos conselhos da França:

E o que tinha sido verdade em Paris em 1871 continuava a ser verdade para a Rússia em 1905, quando as intenções 'não meramente destrutivas, e sim construtivas dos primeiros Sovietes eram tão evidentes que as testemunhas da época 'podiam sentir o surgimento e a formação de uma força que um dia poderá ser capaz de efetuar a transformação do Estado' (ARENDT, 2011, p. 331).

Se havia, tanto na França quanto na Rússia, a crença testemunhada de que os conselhos poderiam efetuar de- 
terminada transformação do Estado, é por que o pulsar da novidade estava presente nessas células de liberdade política.

Arendt (2011, p. 334) salienta que os Sovietes surgiram em todas as partes. Eram espaços públicos que apareceram no meio dos operários, soldados e camponeses. O surgimento dos conselhos em espaços diferenciados revela o potencial de transformação capaz de atingir e transformar a geopolítica de um país. Chama-nos a atenção o fato de esses órgãos se estabelecerem em ambientes diferenciados e de maneira simultânea e, consequentemente, conseguirem se efetivar num movimento de natureza política marcadamente espontânea. É relevante considerarmos as formas de coordenação e integração desse movimento espontâneo admitido por Arendt (2011, p. 334) ao dizer:

O aspecto mais marcante desses desenvolvimentos espontâneos é que bastaram poucas semanas, no caso da Rússia, ou poucos dias, no caso da Hungria, para que esses órgãos independentes e extremamente díspares dessem início a um processo de coordenação e integração por meio da formação de conselhos superiores, de caráter regional ou provincial, dos quais finalmente eram escolhidos os delegados para uma assembleia representando o país inteiro (ARENDT, 2011, p. 334).

Essa articulação permitia que as deliberações em instâncias superiores pudessem refletir as ações elementares da fundação da república em curso. Os Sovietes, desse modo, estavam se constituindo num tipo de organização que possibilitava criar formas de representação que incorporassem as aspirações políticas do país na sua totalidade. A não verticalização do poder permitia que todas as demandas políticas discutidas nos diversos Sovietes, espalhados em seus 
diferentes ambientes, pudessem chegar à mais alta instância de deliberação configurada na grande assembleia que representava o país inteiro. Depreendemos que havia, na articulação dos Sovietes, a adoção de uma estrutura organizacional de caráter horizontal, na qual cada órgão poderia eleger representantes para assembleias superiores, a fim de que se empenhassem em deliberações nunca divorciadas do anseio de todos os participantes dessa estrutura elementar. Sobre como se efetivavam as eleições de representantes de membros dos conselhos, afirma Arendt:

Os membros dos conselhos então escolhiam seus delegados para o conselho logo acima, e esses delegados também eram escolhidos por seus pares sem estarem sujeitos a qualquer pressão de cima ou de baixo. Tal posição era conferida a título exclusivo da confiança de seus iguais, e essa pluralidade não era natural, e sim política; não era nada que lhes fosse inato; era a igualdade daqueles que haviam se comprometido e agora estavam engajados num empreendimento conjunto. Uma vez eleito e enviado ao conselho logo acima, o delegado estava de novo entre os seus pares, pois os delegados em todos os níveis deste sistema eram os que tinham recebido um voto de especial confiança (ARENDT, 2011, p. 347).

Dessa maneira, a eleição de representantes para os conselhos superiores permitia que nunca o representante escolhido deixasse de ser o porta-voz dos representados, uma vez que não podia atuar fora das articulações de deliberações dos conselhos que ficavam logo abaixo. Esse caráter horizontal da representação nos sistemas de conselhos difere substancialmente da representação que ocorre nos ditames da democracia liberal. Nesse sistema, o povo legitima seus representantes para os parlamentos por meio do voto e, a partir daí, deposita neles toda a responsabilidade da ação política. Arendt (2011, p. 300) critica o modelo liberal de 
representação ao dizer que "a representação significa que os votantes abrem mão de seu poder, ainda que voluntariamente, e o velho adágio 'todo poder reside no povo' é válido apenas para o dia da eleição"”.

É imprescindível acentuar que as análises encaminhadas por Arendt acerca do centenário da Revolução Russa de 1917 tornam pertinente o caráter da fundação de um novo corpo político presente na vida dos Sovietes. Para tanto, Arendt (2004, p. 199) apresenta algumas características que reforçam o caráter republicano desses órgãos. Nesse ideal de fundação, temos uma nova forma de governo baseada em um sistema de conselhos, que, como se sabe, pereceu em todo lugar e em toda época. Essa nova forma de governo foi destruída pela burocracia dos Estados-nações ou pelas estruturas das máquinas partidárias. Se esse sistema, aponta Arendt (2004, p. 199), for considerado uma pura utopia, seria, de qualquer maneira, como utopia tipicamente assumida pelo povo, considerando que esse tipo de utopia que havia nesses espaços públicos não era a utopia anunciada por teóricos e ideólogos. Anuncia Arendt:

Esses observadores viam os conselhos como um sonho romântico, alguma espécie de utopia fanática que se materializava por um rápido instante apenas para mostrar como eram fantasiosos os anseios românticos do povo, que pareciam desconhecer as realidades da vida. Esses realistas se respaldavam no sistema partidário tomando como um dado de fato que não existia nenhuma outra alternativa ao governo representativo e esquecendo convenientemente que a queda do velho regime se devia, entre outras coisas, justamente a esse sistema (ARENDT, 2011, p. 329-324).

Percebemos que os teóricos e ideólogos defensores do sistema partidário, além de desprezarem que foram os con- 
selhos os principais responsáveis pela queda do velho regime - cabe lembrar aqui o Antigo Regime na França e o Czarismo na Rússia -, também consideravam utópicas e românticas aquelas experiências que não fossem de governo representativo. No entanto, Arendt (2004, p. 199) afirma que não se pode dizer que essa experiência de conselhos era realmente uma utopia ${ }^{6}$, porém certifica que o sistema de conselhos brotou da própria experiência espontânea da ação política dos seus participantes e ocorreu em todas as revoluções. Os conselhos foram mola-mestra para a fundação de novas realidades políticas, a exemplo dos acontecimentos de 1917 na Rússia.

\section{LÊNIN NO PODER}

A Rússia sempre foi um país com grandes extensões territoriais e com características culturais e políticas dotadas de singularidades, as quais a tornam diferente de outros países. Arendt (1989, p. 368), em suas considerações sobre o desempenho da Revolução de 1917, salienta que se tratou de vitória que ocorreu num país onde havia uma burocracia despótica e centralizada. Naquele contexto, a Rússia possuía uma massa populacional marcada pela desestruturação.

\footnotetext{
${ }^{6}$ A referência ao sistema de conselhos como possível utopia aparece nas análises de Arendt (2004, p. 199), no sentido de que a pensadora parece tentar buscar responder aos críticos do sistema de conselhos que tal sistema pode até ser considerado uma utopia caso se compreenda que seja de qualquer modo uma utopia do povo, não a utopia proclamada por teóricos e ideólogos. Estamos falando aqui de um sistema de uma nova forma de governo que não se enquadra na perspectiva de um projeto ou ação irrealizável. Pelo contrário, foi sim uma experiência de ação política, a saber: "E mais, estes sistemas de conselhos nunca apareceram como resultado de uma tradição ou teoria revolucionária consciente, mas de um modo totalmente espontâneo, cada vez como se nunca tivesse havido nada semelhante antes. Assim, o sistema de conselho parece corresponder e brotar da própria experiência da ação política”.
} 
Não se poderia dizer que a Rússia daquela época se enquadrava nos elementos da ordem feudal rural, tampouco nas classes capitalistas urbanas que estavam nascendo, porque elas eram carregadas de debilidade. Lênin considerou que, diferentemente de outras partes do mundo, a vitória da Revolução de outubro foi marcada pela facilidade. Mas, se por um lado Lênin considerou fácil galgar o poder na Rússia, por outro admitiu que fosse difícil conservá-lo. O alerta arendtiano a respeito dessa afirmação de Lênin se orienta no sentido de que ele tinha consciência da fragilidade da classe operária russa, bem como das anárquicas condições sociais que, de maneira geral, tornavam propícia a realização de mudanças súbitas. As chamadas anárquicas condições sociais sugerem ser um conjunto de insatisfação decorrente da citada fragilidade das classes operárias e, provavelmente, também das classes camponesas que geravam certa instabilidade. Se Arendt se refere a elas como propícias de realização de mudanças típicas, talvez seja essa a razão pela qual ocorre a demonstração de insatisfações por parte dessas classes socialmente menos favorecidas.

Naquele contexto de movimentação da liderança de Lênin, Arendt (1989, p. 368-369) diz que existia na Rússia donos de terras que tiveram suas propriedades expropriadas pelos camponeses. Existia uma frágil classe operária que demonstra que a Rússia não era um país fortemente industrializado. Havia uma tímida classe média, além da existência de tribos mais primitivas. Todavia, essa composição de classes que existia na Rússia, no contexto da liderança de Lênin, mostra que, se havia uma tímida classe média e uma frágil classe operária, aquele país não poderia se enquadrar nos parâmetros que configuram suas classes como classes 
capitalistas urbanas significativas, tampouco um país composto por essas classes já não poderia ser enquadrado como um país dominado por elementos da ordem feudal rural.

O primeiro líder da Rússia revolucionária, com o objetivo de salvar a Revolução, tratou de tomar algumas medidas abordadas por Arendt:

Legalizou a anárquica expropriação dos donos de terra pelos camponeses, e assim estabeleceu na Rússia, pela primeira vez e provavelmente a última, aquela classe camponesa emancipada que, desde a Revolução Francesa, havia sido o mais firme esteio dos Estadosnações ocidentais. Tentou fortalecer a classe trabalhadora encorajando os sindicatos independentes. Tolerou a tímida aparição de uma nova classe média proveniente da NEP [Nova Política Econômical após o fim da guerra civil. Introduziu outras formas de distinção, organizando e, às vezes, até inventando o maior número possível de nacionalidades, fomentando a consciência nacional e a percepção de diferenças históricas e culturais mesmo entre as tribos mais primitivas da União Soviética (ARENDT, 1989, p. 368-369).

Embora façamos aqui referência às tribos mais antigas da União Soviética, é primordial ressaltar que, para a nossa autora, a passagem definitiva da Rússia para a União Soviética somente ocorreu em 1930, no momento do reconhecimento pela maioria dos Estados e quando não havia mais o perigo da intervenção do exterior. Nas palavras de Arendt (1989, p. 370-371): “A intervenção do exterior, que poderia apoiar um dos setores descontentes da população, já não constituía perigo em 1930, quando a União Soviética, já reconhecida pela maioria dos Estados e firmemente implantada, tornou-se a parceira do sistema nacional vigente". Percebemos que Lênin procurou agir no governo buscando mostrar que era possível fundar uma nova Rússia. Ele apostava no desenvolvimento econômico e social daquela imen- 
sa porção do povo eslavo. Por essa razão, apresentou à população daquele país um projeto de nação. Arendt (1989, p. 369) vê nessas medidas questões de caráter político puramente prático. Temos, nesse pragmatismo de Lênin, a demonstração de que ele possuía e prosseguia com seus instintos de estadista.

Alerta Arendt (1989, p. 369) que o temor de Lênin estava em ter que lidar com a ausência de uma estrutura social. Dessa maneira, Arendt (2011, p. 100) lembra-nos que Lênin teria dito numa frase aquilo que poderia ser considerado a essência e os objetivos da Revolução Russa de 1917: "Eletrificação + Sovietes". Com essa afirmação, Lênin estava procurando omitir duas questões fundamentais: o papel do Partido e a construção do socialismo. A análise arendtiana concebe que, ao se referir à questão da eletrificação, Lênin estava almejando uma solução para o problema social na Rússia e, ao se referir aos Sovietes, o líder da Revolução de outubro estava pleiteando um novo corpo político que abarcasse esses conselhos nascidos no seio da Revolução e que não se enquadravam nos liames de qualquer tipo de organização de cunho partidário. Com o programa de eletrificação, Lênin, ao almejar resolver um problema de cunho social, deixa-nos claro que não é somente pela via da implantação do socialismo que podemos lidar com a solução de questões sociais. Ao omitir naquele contexto a construção do socialismo, Lênin não esconde que suas medidas iniciais tiveram êxito sem a consolidação do socialismo. E a necessidade de eletrificação denuncia o quanto havia de problemas sociais e econômicos na Rússia das primeiras décadas do século XX.

A opção de Lênin de governar pela eletrificação diz 
muito acerca da questão social da Rússia daquele contexto histórico. Nesse sentido, Arendt (2011, p. 100) considera surpreendente o fato de um líder, que possuía filiação ao ideal marxista, aderir ao propósito de que a pobreza não se resolveria pelas formas de socialização e de socialismo. A aposta de Lênin, segundo as análises arendtianas, é a de que a solução para combater a pobreza na Rússia teria que passar, antes de tudo, por meios técnicos, considerando que, ao lançar mão da tecnologia, estava se optando por uma medida politicamente neutra e que poderia ocorrer em qualquer forma de governo. Ou seja, o entendimento de Lênin, na interpretação de Arendt (2011, p. 100), é de que "a tecnologia, em contraste com a socialização, é politicamente neutra; ela não prescreve e nem exclui nenhuma forma específica de governo". Se naquele momento não interessava a Lênin consolidar a implantação do socialismo, a opção por eletrificação, que se faz por tecnologia, implicaria, com a sua suposta neutralidade, buscar resolver um dos principais problemas sociais da Rússia.

A adesão de Lênin à pauta da eletrificação possui, conforme Arendt (2011, p. 100), o significado de uma ação de governo, cujo objetivo era libertar os russos que se encontravam diante da calamidade da pobreza. Porém, a liberdade, no seu sentido político, só poderia ser alcançada por meio da manutenção dos Sovietes. Manter a eletrificação ${ }^{7}$

\footnotetext{
${ }^{7}$ A respeito do entendimento assumido por Lênin no momento em que optou por abandonar quase por inteiro a convicção de que o poder seria dos Sovietes, diz Arendt (2011, p. 100-101): "Ele acreditava que um povo incompetente num país atrasado não conseguiria vencer a pobreza em condições de liberdade política, não conseguiria, em todo caso, derrotar a pobreza e simultaneamente instaurar a liberdade. Lênin foi o último herdeiro da Revolução Francesa. Ele não tinha nenhum conceito teórico da liberdade, mas, posto diante dela na realidade concreta, entendeu o que estava em jogo e, quando sacrificou as novas instituições da liberdade, os Sovietes, ao partido Cont.
} 
objetivando a libertação da questão social, e preservar os Sovietes para garantir a liberdade política dessa nova forma de governo significaram, para Arendt (2011, p. 100), que "esse foi um dos não raros casos em que os dotes de Lênin como estadista prevaleceram sobre sua formação e convicção ideológica marxista”.

Mas, na perspectiva de Arendt (2011, p. 100), esse comportamento de estadista, que de alguma maneira ainda buscava preservar o potencial de liberdade política dos Sovietes, não prevaleceu por muito tempo. Lênin optou por fazer do Partido Bolchevique a força que iria movimentar tanto a eletrificação quanto os Sovietes. Os rumos tomados pelo governo de Lênin estariam, em termos arendtianos, abrindo precedente para o desenvolvimento posterior em que o Partido, com toda a sua máquina, se tornaria onipotente. Contudo, Arendt enfatiza:

Sem dúvida, Lênin sofreu sua maior derrota quando o espocar da guerra civil, o supremo poder que ele originalmente planejava concentrar nos Sovietes, passou definitivamente às mãos da burocracia do Partido; mas mesmo isto, trágico como era para o curso da Revolução, não teria levado necessariamente ao totalitarismo (ARENDT, 1989, p. 369).

Percebemos, a partir dessa abordagem, que Arendt apresenta-nos um momento do governo da Rússia, nascido com o advento da Revolução de 1917, no qual o poder de sedução da burocracia partidária avançava sobre os espaços de liberdade política presentes no seio dos Sovietes. Algo considerado trágico para Arendt, uma vez que aquele mo-

que julgou que libertaria os pobres, sua motivação e seu raciocínio ainda estavam de acordo com os trágicos fracassos da tradição revolucionária francesa”. 
mento significou um desvio de rota das pretensões originárias da Revolução, que brotaram em vários espaços da sociedade russa das duas primeiras décadas do século XX. A almejada fundação de uma nova forma de governo na Rússia, caracterizada por bases republicanas e que foram progressivamente alinhavadas nos diversos Sovietes, estava ameaçada.

No que diz respeito ao conflito entre Partido e conselhos, trata-se de algo que não surgiu pela primeira vez no contexto da Revolução Russa. Ele existiu na Revolução Francesa. A França conviveu com uma grande quantidade de clubes e sociedades - as sociétés populaires. Eram espaços de manifestação da liberdade política. Na ótica de Arendt (2011, p. 303), Robespierre compreendia que "as sociedades populares eram os únicos lugares no país onde essa liberdade podia realmente se mostrar e ser exercida pelos cidadãos". Acreditava-se que as sociedades se constituíam como verdadeiros "pilares da Constituição", pois, no seu interior, manifestavam-se as "fundações da liberdade". Visto dessa maneira, qualquer um que demonstrasse o interesse de interferir em suas reuniões estaria, em boa medida, "atacando a liberdade". Arendt (2011, p. 303-304) diz que assim que Robespierre assumiu o poder na França, utilizou-se da condição de líder político do então governo revolucionário e assumiu completamente uma outra posição. Sua ascensão ao poder representou o início de um combate incansável às sociedades populares. Tomou como medida a substituição das sociedades pelo que ele chamou de "a grande sociedade popular de todo o povo francês", de caráter uno e indivisível. Essa "grande sociedade popular de todo o povo francês" deveria se reunir num espaço capaz de 
comportar todos os que iriam representar o povo francês. Seria um espaço que contemplasse os trabalhos da representação no âmbito da Câmara de Deputados. Criou-se, a partir daí, uma instituição que assumiria o papel de tomar em suas mãos o poder indivisível e centralizado de toda a nação francesa.

Arendt (2011, p. 312) nos lembra de que o conflito entre Partido e conselhos ocorre porque "o conflito entre os dois sistemas sempre foi, na verdade, um conflito entre o parlamento, fonte e sede do poder do sistema partidário, e o povo, que entregou o poder a seus representantes". $\mathrm{O}$ conflito entre partidos e conselhos se sustentava, uma vez que esses últimos não se contentavam em abandonar a participação direta acerca dos assuntos do país. Isto é, diferentemente dos partidos, Arendt (2011, p. 329) recorda que "os conselhos desejavam explicitamente a participação direta de todos os cidadãos nos assuntos públicos do país". Semelhante ao que aconteceu na França de Robespierre, Arendt afirma que, no caso da Rússia:

Se Lênin realmente quisesse dar todo o poder aos sovietes, ele condenaria o Partido Bolchevique à mesma impotência que agora é a característica dominante do Parlamento soviético, cujos deputados filiados e não filiados são indicados pelo partido, e na ausência de qualquer outra lista, nem sequer são escolhidos, e sim apenas aclamados pelos eleitores (ARENDT, 2011, p. 332).

Embora tenha ocorrido, por parte do primeiro líder da revolução Russa, a tentativa de diminuição do poder dos Sovietes, Arendt (1989, p. 369) realça que, no momento derradeiro da vida de Lênin, não havia ainda na Rússia uma sociedade dominada pelo totalitarismo, pois os caminhos encontravam-se abertos. Naquele momento, a Rússia 
contava com uma agricultura desenvolvida em base coletiva, de maneira cooperativa ou privada. $\mathrm{O}$ ambiente econômico era de formato nacional e estava livre para prosseguir num padrão capitalista, estatal de cunho capitalista ou até mesmo de mercado. Encaminhadas dessa forma, a pensadora expõe que nenhuma dessas opções teria sido capaz de destruir, de maneira automática, a nova estrutura do país deixada por Lênin. Arendt enfatiza também que todas essas classes e nacionalidades que compunham a sociedade russa daquele momento poderiam ser consideradas portadoras de força capaz de barrar o caminho de Stalin. Caminho esse apontado por Arendt quando Stalin iniciou o seu trabalho de preparar o país para a consolidação de um governo marcadamente totalitário.

\section{STALIN E O DOMÍNIO TOTAL}

Diante de uma Rússia que nos primeiros anos de sua Revolução fora conduzida pela Nova Política Econômica (NEP), Arendt (1989, p. 369-370) nos esclarece que os caminhos inicialmente trilhados por Stalin possuíam alguns obstáculos que poderiam tornar mais difíceis a sua saga totalitária. $\mathrm{Na}$ condição de sucessor de Lênin, Stalin empreendeu a tarefa de liquidar o resto do poder que ainda restava aos Sovietes. Stalin objetivou criar uma massa atomizada e amorfa. Todavia, esse objetivo não poderia ser alcançado na convivência com os espaços de liberdade política a exemplo dos Sovietes.

Arendt (1989, p. 369-370) assegura que, no momento da ascensão do stalinismo ao governo, os Sovietes ainda possuíam um tipo de poder que se configurava numa repre- 
sentação nacional, a qual, naquelas circunstâncias, era capaz de impedir o domínio absoluto da hierarquia do Partido Bolchevique. Portanto, a primeira medida de Stalin, rumo ao estabelecimento do poder de domínio total, foi debilitar os Sovietes nacionais.

Aponta a análise arendtiana que, para concretizar esses propósitos, Stalin introduziu nos Sovietes células bolchevistas, das quais sairiam, com certa exclusividade, os funcionários de escalões superiores para ocupar espaços nos comitês centrais. Essa investida stalinista, ocorrida por volta de 1930, culminou com o desaparecimento dos últimos vestígios dos Sovietes. A investida de Stalin contra os Sovietes consistiu na propagação do terror ${ }^{8}$. Naquele momento, desapareciam na Rússia os últimos vestígios de sua inédita experiência de conselhos admitidos na abordagem arendtiana como instituições comunais. $\mathrm{O}$ stalinismo, ao conseguir pôr fim à existência dos Sovietes, colocou no lugar desses antigos espaços públicos de liberdade uma burocracia partidária marcadamente centralizada.

Num segundo momento, a estratégia de domínio de Stalin, segundo Arendt (1989, p. 370), aponta para o seu empreendimento, a fim de colocar em prática o objetivo que visava à liquidação das classes. Nessa tarefa, Stalin se utilizou de instrumentos como a ideologia e a propaganda. As classes que entraram na mira de Stalin foram: as propri-

\footnotetext{
${ }^{8}$ Referindo-se ao terror empreendido pelo governo totalitário, Arendt (1989, p. 518) salienta: "Pressionando os homens, uns contra os outros, o terror total destrói o espaço entre eles; comparado às condições que prevalecem dentro do cinturão de ferro, até mesmo o deserto da tirania, por ainda constituir algum tipo de espaço, parece uma garantia de liberdade. O governo totalitário não restringe simplesmente os direitos nem simplesmente suprime as liberdades essenciais; tampouco, pelo menos ao que saibamos, consegue erradicar do coração dos homens o amor à liberdade, que é simplesmente a capacidade de mover-se, a qual não pode existir sem espaço".
} 
etárias, a nova classe média que vivia nas cidades e os camponeses. Não é possível para um governo que busca o domínio total conviver lado a lado com a existência de classes potencialmente capazes de se oporem ao regime.

Arendt (1989, p. 370), ao tratar da investida stalinista contra os camponeses, adverte que ela foi mais meticulosa e cruel quando comparada às ações empreendidas aos outros grupos. O motivo dessa investida residia no fato de ter sido a classe dos camponeses, devido ao seu grande número, potencialmente a classe mais poderosa da União Soviética. A crueldade investida contra os camponeses foi efetivada por meio de deportações e fome, uma vez que possuía o intuito de expropriar os kulaks ${ }^{9}$ a coletivização. Após a Revolução de 1917, o processo de coletivização e o reforço que buscava interesses comuns criaram uma nova classe agrícola, a qual passou a incomodar o governo stalinista. Dito de outro modo, no entendimento arendtiano, os camponeses se constituíram numa classe que se utilizou de um tipo de coletivização e de esforços ligados a interesses comuns. Por esse motivo, essa classe passou a representar, de maneira latente, um perigo iminente para o governo totalitário. Os camponeses, naquele momento da história da Rússia, possuíam uma posição relevante para a economia do país. $\mathrm{O}$ interesse de Stalin era transformar as fazendas coletivas em unidades maiores.

A ânsia do stalinismo de chegar a um governo caracterizado pelo domínio total, ao mesmo tempo em que se bus-

\footnotetext{
9 Sobre essa questão, Bobbio, Matteucci e Pasquino (2010, p. 1222) afirmam: "A produção agrícola, após ter passado por diversas fases, foi, por fim, completa e bruscamente coletivizada. Este processo chocou contra a tenaz oposição dos kulaki ou camponeses ricos, que foram totalmente expropriados e exterminados em massa".
} 
cava eliminar os camponeses, voltou-se para a classe média oriunda dos resultados da NEP. O domínio total se caracteriza pela insistência em liquidar as forças de resistência presentes em todas as classes ${ }^{10}$. A classe média era uma classe tolerada por Lênin, mas que não teve o mesmo destino com Stalin, pois ele não deixou de promover a sua extinção. Arendt revela que a liquidação da classe média ocorreu no início da década de 1930 e completa:

Os que não se incluíam entre os muitos milhões de mortos ou milhões de deportados sabiam agora 'quem mandava neste país' e haviam compreendido que as suas vidas e as vidas de suas famílias não dependiam de seus concidadãos, mas somente dos caprichos do governo, aos quais tinham de enfrentar completa solidão, sem qualquer tipo de auxílio do grupo a que pertencessem (ARENDT, 1989, p. 370).

Notamos que não ser incluído entre os mortos era também tornar-se morto para a sua classe. Não havia mais dependências em relação aos concidadãos de classe. A classe média, antes tolerada e possuidora de certa autonomia de associação, tornou-se, por ora, objeto de capricho do governo, que buscava insistentemente alcançar o domínio total.

Arendt (1989, p. 370) registra que a terceira classe a ser liquidada como grupo foi a dos operários. A autora apontanos que a classe operária se encontrava em situação de maior debilidade em relação aos camponeses; por esse motivo,

\footnotetext{
${ }^{10}$ Sobre isso, completa Arendt (1989, p. 512): "Sempre que galgou o poder, o totalitarismo criou instituições políticas inteiramente novas e destruiu todas as tradições sociais, legais e políticas do país. Independentemente da tradição especificamente nacional ou da fonte espiritual particular da sua ideologia, o governo totalitário sempre transformou as classes em massas, substituiu o sistema partidário não por ditaduras unipartidárias, mas por um movimento de massa, transferiu o centro do poder do Exército para a polícia e estabeleceu uma política exterior que visava abertamente ao domínio mundial".
} 
ofereciam menos resistência. Durante a eclosão da Revolução de 1917, os operários haviam feito espontaneamente a expropriação dos donos das fábricas. Porém, tal expropriação foi posteriormente frustrada, porque o governo confiscara as fábricas tornando-as propriedade do Estado. O confisco das fábricas pelo governo se pautou no argumento pretensioso de que esses meios de produção pertenciam ao proletariado.

A análise arendtiana esclarece que o governo stalinista criou, no início da década de 1930, o sistema stakhanovista, que tratou de eliminar a solidariedade e a consciência de classe entre os trabalhadores. No lugar do sentimento de solidariedade e de pertencimento a uma classe, o sistema stakhanovista implantou a concorrência feroz por meio da solidificação de uma aristocracia operária, a qual era separada do trabalhador comum. Essa aristocracia foi separada dos demais trabalhadores de maneira mais aguda do que a distância entre tais trabalhadores e a gerência. A investida stalinista contra os operários atingiu o seu apogeu em 1938 com a criação de um documento de trabalho, que transformou oficialmente toda a classe operária do território russo num enorme corpo de trabalhadores forçados.

Arendt (1989, p. 371) salienta que, após ter eliminado as condições de classe dos camponeses, da classe média urbana e dos operários, Stalin investiu na liquidação daquela burocracia que anteriormente havia sido o instrumento de execução dessas classes. O líder totalitário levou dois anos, isto é, de 1936 a 1938, para liquidar toda a aristocracia presente nos campos das atividades militares e administrativas. A investida do domínio totalitário stalinista se dirigiu às repartições públicas, fábricas, entidades econômicas e de cu- 
nho cultural, bem como às agências governamentais e partidárias. Stalin passou para outras mãos a direção de todas essas atividades. A guerra de força utilizada por Stalin com esses grupos foi muita violenta. Arendt (1989, p. 371) adverte que "'quase a metade do pessoal administrativo, do partido ou não, havia sido eliminada', e foram liquidados mais de $50 \%$ de todos os membros do partido e "pelo menos outras 8 milhões de pessoas"”.

A destruição da burocracia, que antes foi suporte para a eliminação de outras classes, demonstra o nível de dominação a que chegaram as pretensões do stalinismo. O objetivo maior para se atingir o domínio total ocorreu de fato no momento quando calou e perseguiu toda a força de grupos oposicionistas. Liquidar classes não bastou para as pretensões do domínio total stalinista. Foi preciso eliminar os camaradas do Partido, que, por um motivo ou outro, viessem a divergir do poder central. Nesse sentido, qualquer atividade política, que não fosse a do poder de domínio totalitário, era passível de ameaça a esse poder instituído. Dito em outras palavras, o totalitarismo não permite atividade política, que está intimamente vinculada com a liberdade. Trata-se de dominação, não de ação política tal como ela é compreendida em termos arendtianos. Isso fica evidente na maneira como salienta Arendt:

A oposição ativa e organizada havia cessado de existir por volta de 1930 quando Stalin, em seu discurso no Décimo Sexto Congresso do Partido, declarou ilegais as divergências ideológicas dentro do partido, sendo que mesmo essa frouxa oposição mal pudera basear-se em alguma classe existente. $O$ terror ditatorial - que difere do terror totalitário por ameaçar apenas adversários autênticos, mas não cidadãos inofensivos e carentes de opiniões políticas - havia sido suficientemente implacável para sufocar toda a atividade política, 
ostensiva ou clandestina, mesmo antes da morte de Lênin (ARENDT, 1989, p. 371).

Notamos que a perseguição implacável de Stalin a todas as forças políticas internas e externas ao Partido, que se opunham ao projeto de implantação do domínio total, se consolidou na década de 30 do século XX. Inaugurou-se, a partir daí, um regime que seguiu se instaurando diferentemente do terror ditatorial. Muito além disso, temos a implantação definitiva do regime totalitário na versão stalinista. Podemos dizer que o advento do totalitarismo stalinista pôs fim a todo e qualquer resquício do ideal de fundação republicano que estava presente nos Sovietes, os quais muito contribuíram para a eclosão da Revolução Russa de 1917. Sem a presença dos Sovietes na cena política, e com a implantação do totalitarismo na União Soviética, é como se a Revolução tivesse chegado ao seu fim. Dessa maneira, tomando como base as análises arendtianas, podemos dizer que a ruína da Revolução Russa de 1917 ocorre a partir da ascensão de Stalin ao poder do governo da Rússia.

\section{AS REVELAÇÕES DE NIKITA KHRUSHCHEV E OS SINAIS DE DESTOTALITARIZAÇÃO DA UNIÃO SOVIÉTICA}

Diferentemente do ocorrido na Alemanha, Arendt (1989, p. 340) afirma que, com o término da guerra em 1945, o governo totalitário não havia chegado ao fim na Rússia. Além disso, o que ocorreu foi o contrário, pois o regime de Stalin ampliou seus tentáculos de domínio total por toda a Europa Oriental. Mas algo mudou na geopolítica da então União Soviética nos oito anos que se seguiram após a morte de Stalin. O substituto de Stalin foi Nikita Khrushchev. 
Tratava-se de um membro do Partido que galgou poder em sua hierarquia. Apesar de ser alguém que, para assumir poderes hierárquicos no Partido, se utilizou de encaminhamentos de caráter repressivos antes efetivados por Stalin ${ }^{11}$, Khrushchev iria denunciar alguns crimes cometidos pelo regime, embora ele não ousasse revelar a criminalidade cometida pelo regime na totalidade. Nesse caso, Arendt $(1989$, p. 344) alerta que intelectuais e jovens russos, independentemente do que Khrushchev havia anunciado, tinham conhecimento dos "expurgos em massa e deportação e aniquilação de povos inteiros" promovidos pelo regime de domínio total liderado por Stalin. O alerta arendtiano denuncia como simplória a alusão de demência conferida a Stalin por Khrushchev.

Podemos dizer que há algo de relevante nas denúncias de Khrushchev se considerarmos que, pela primeira vez, o regime admitiu que houvesse cometido crimes ${ }^{12}$ mesmo que

\footnotetext{
${ }^{11}$ Arendt (1989, p. 349) faz referências à maneira pela qual Khrushchev ascendeu ao poder: "Tecnicamente, o golpe de Khrushchev seguiu muito de perto os métodos do seu falecido e denunciado mestre. Ele também precisou de uma força externa para galgar o poder na hierarquia do partido, e usou o apoio do marechal Zhukov e do Exército exatamente do mesmo modo como Stalin havia usado suas relações com a polícia secreta na luta sucessória de trinta anos antes. Tal como no caso de Stalin, quando o poder supremo depois do golpe continuou a residir no partido, e não na polícia, também no caso de Khrushchev, 'em fins de 1957 o partido Comunista da União Soviética havia alcançado uma posição de supremacia inconteste em todos os aspectos da vida soviética', porque, do mesmo modo como Stalin jamais hesitara em expurgar os seus escalões policiais e liquidar o seu chefe, também Khrushchev havia imitado suas manobras intrapartidárias removendo Zhukov do Presidium e do Comitê Central do Partido, ao qual havia sido eleito após o golpe, além de afastá-lo do posto de mais alto comandante do Exército”.

${ }^{12}$ Para muitos admiradores do regime stalinista, foi chocante e causou confusão nos espíritos saber que se tratava de um regime que violou os direitos humanos. Lefort $(2011$, p. 60) adverte: "Todos sabem de onde veio o choque. A descoberta da amplitude do sistema concentracionário na União Soviética graças a uma torrente de informações difundidas pelas vítimas do Gulag, entre as quais e primeiramente Soljenitsin, em seguida as iniciativas dos dissidentes no conjunto dos Estados socialistas tirando partido dos acordos de Helsinque para exigir o respeito aos direitos do homem semearam a maior confusão nos espíritos".
} 
fosse por "demência" de seu líder. Os expurgos cometidos por Stalin já eram conhecidos no seio da sociedade russa. Arendt (1989, p. 345) diz que eles eram conhecidos no arquivo de Smolensk, o qual "é ainda sem dúvida o mais importante documento", que registrou várias atrocidades cometidas pelo domínio total stalinista.

Após a morte de Stalin, começou a se constituir um processo de destotalitarização da União Soviética, anunciado por Arendt da seguinte maneira:

Mencionei antes o processo de destotalitarização que se seguiu à morte de Stalin. Em 1958, eu ainda não estava certa de que o 'desgelo' fosse mais que um relaxamento temporário, uma espécie de medida de emergência devida à crise de sucessão, não muito diferente do afrouxamento dos controles totalitários durante a Segunda Guerra Mundial. Ainda hoje, não podemos saber se esse processo é final e irreversível, mas já não podemos chamá-lo de temporário ou provisório. Pois, como quer que interpretemos a linha sinuosa e frequentemente desnorteante da política soviética desde 1953, é inegável que o enorme império policial foi liquidado, que a maioria dos campos de concentração foi dissolvida, que não houve mais expurgos de 'inimigos objetivos' e que os conflitos entre os membros da nova 'liderança coletiva' são agora resolvidos pela remoção e pelo exílio, e não por julgamentos ostensivos, confissões e assassinatos (ARENDT, 1989, p. 345).

Percebemos que as diferenciações destacadas por Arendt, no que tange ao período quando Stalin esteve no poder, bem como os fatos ocorridos no governo após a sua morte, buscam realçar a relevância das mudanças efetuadas pelos novos governantes. Arendt menciona um processo de mudança que, podendo ser irreversível ou não, já não poderia mais ser considerado temporário. A ausência do im- 
pério policial, a dissolução dos campos de concentração, o fim dos expurgos dos "inimigos objetivos" ${ }^{3}$ e, até mesmo, o fim de julgamentos ostensivos de confissões forçadas e de assassinados constituíam medidas que comprovam as diferenciações em relação ao stalinismo. Os julgamentos de maneira ostensiva, seguidos de confissões impostas e assassinatos, foram substituídos pelas remoções e exílios. Tratar de medidas como remoções e exílios, considerando-as como parte de certo degelo, parece-nos estranho, uma vez que se trata de medidas ainda cruéis. No entanto, se comparados com as torturas e os assassinatos que eram cometidos durante a vigência do stalinismo, havia na União Soviética dos anos 1960 elementos que comprovam a concepção arendtiana de que os tempos políticos eram de destotalitarização. Para Arendt (1989, p. 345), há outros sinais ${ }^{14}$ de que a

\footnotetext{
${ }^{13}$ A concepção de "inimigo objetivo" é admitida por Arendt (1989, p. 474) da seguinte maneira: "A introdução da noção de 'inimigo objetivo' é muito mais decisiva para o funcionamento dos regimes totalitários que as definições ideológicas das respectivas categorias. Os bolchevistas, tendo começado com os descendentes das antigas classes governamentais, dirigiram todo o seu terror contra os kulaks (no começo da década de 30), que por sua vez foram seguidos pelos russos de origem polonesa (entre1936 e 1938), os tártaros alemães do Volga (durante a Segunda Guerra), os antigos prisioneiros de guerra e unidades das forças de ocupação do Exército Vermelho (depois da guerra) e finalmente a população judaica tachada de cosmopolita (depois de um estabelecimento de um Estado judaico). A escolha dessas categorias nunca é inteiramente arbitrária; uma vez que são divulgadas e usadas para fins de propaganda do movimento no exterior, devem parecer plausíveis como possiveis inimigos; a escolha de uma determinada categoria pode até ser motivada por certas necessidades de propaganda do movimento em geral - como, por exemplo, o repentino surgimento do antissemitismo governamental na União Soviética, inteiramente sem precedentes, cuja finalidade pode ter sido a de angariar simpatias para a União Soviética nos países satélites europeus".

${ }^{14}$ Em 1979, Claude Lefort (2011, p. 60) advertiu-nos acerca desses sinais: "Observamos que o que há de mais novo na conjuntura desses últimos anos na União Soviética, na Europa do Leste e também na China não são indivíduos protestando contra o arbítrio da polícia, denunciando a sujeição dos tribunais ao Estado, exigindo liberdades definidas, mas sim colocando sua ação sob o signo da defesa dos direitos do homem; o que há de mais novo é a perseguição que sofrem por suas opiniões, que sejam condenados sem que possam defender-se, mas sim que os direitos do homem se tornem, através deles, o alvo do poder. Além do duro fato da coerção exercida contra indivíduos e grupos, tornou-se assim manifesta uma oposição fundamental entre um modelo de Cont.
} 
União Soviética, após a morte de Stalin, já não podia mais ser considerada um país de regime totalitário. Essa afirmação se fundamenta no crescimento fecundo das artes. A expansão das artes se deu em meio à ameaça do surgimento de esforços que tentavam reabilitar o stalinismo e, consequentemente, colocar freios nas liberdades de expressão e de pensamento. Tais liberdades eram crescentes nos estudantes, escritores e artistas.

O período de Khrushchev no poder representou um momento no qual a União Soviética respirava ares mais leves e, por esse motivo, se diferenciava da época dos grandes expurgos promovidos por Stalin. Sobre esse período, Arendt $(1989$, p. 350) afirma: "Sem dúvida, o povo da União Soviética não tem qualquer forma de liberdade política; falta-lhe não apenas a liberdade de associação, mas também a liberdade de pensamento, opinião e expressão pública. Nada parece ter mudado; mas, de fato, tudo mudou". Apesar dessas faltas de manifestações de liberdade, Arendt insiste em mostrar a diferenciação desse momento quando ele é relacionado à era de Stalin no poder. Por essa razão, completa:

Quando Stalin morreu, as gavetas dos escritores e dos artistas estavam vazias; hoje, existe toda uma literatura que circula em forma de manuscrito, e toda forma de pintura moderna é experimentada nos estúdios dos pintores e se torna conhecida, embora não possa ser exibida. Não pretendemos minimizar a diferença entre a censura tirânica e a liberdade das artes, mas apenas acentuar o fato de que a diferença entre uma literatura clandestina e nenhuma literatura é igual à diferença entre um e zero (ARENDT, 1989, p. 350).

sociedade totalitária (quaisquer que sejam as múltiplas variantes, stalinista ou neostalinista, maoísta ou neomaoista) e um modelo que implica o reconhecimento dos direitos". 
Evidenciamos a cautelosa tentativa de Arendt em demonstrar que a ausência de várias manifestações de liberdades em espaços de natureza política e de pensamento não significou a ausência absoluta de todas as formas pelas quais a liberdade possa se manifestar. $\mathrm{O}$ simples fato de a liberdade das artes voltar a pulsar alguns anos após a morte de Stalin já permitia, na perspectiva arendtiana, vislumbrar a configuração de uma diferenciação a ser destacada. Antes na clandestinidade, as artes não estavam mais ocupando o espaço das gavetas. Arendt se refere a um novo tempo na União Soviética, no qual a pintura estava sendo exibida mesmo que tal exibição ocorresse somente nos espaços dos estúdios. Esses espaços de manifestações artísticas e literárias não poderiam ser mais ignorados como fatores de diferenciação do período político anterior. A circulação literária por meio de manuscritos e a pintura revelada em estúdios demonstravam o quanto a destotalitarização anunciava uma realidade plausível aos olhos de Arendt.

\section{CONSIDERAÇÕES FINAIS}

Vimos que Arendt faz significativas referências à experiência dos Sovietes; ou seja, os conselhos nascidos em diversos ambientes da sociedade russa que prepararam o caminho para a eclosão da Revolução de 1917. Com o advento da Revolução Russa e, consequentemente, no momento em que os seus principais líderes ascenderam ao poder, essa experiência de ação política não teve prosseguimento.

Nas comemorações do centenário da Revolução Russa, Arendt provavelmente estaria, por um lado, chamando-nos a atenção para a importância dos ideais republicanos que 
nortearam a fundação proposta pelos membros dos Sovietes; por outro, estaria enfatizando que esses ideais presentes na eclosão revolucionária, lamentavelmente, foram posteriormente eliminados pelo poder do domínio total stalinista. A perda desses ideais inspiradores da Revolução Russa, presentes nos Sovietes, significou, para Arendt, a perda de um tesouro que, em outras palavras, é a perda da liberdade política na versão de um republicanismo contemporâneo.

Abstract: In dealing with the action of contemporary man with regard to the Russian Revolution, Hannah Arendt elaborates approaches in the field of political philosophy. These are approaches that certainly can illuminate the present time, especially when we celebrate the centenary of this important rupture in 1917. In her analysis, the author tries to demonstrate that the experiences of the Soviet-style councils in Russia were strengthened from the movements of 1905 by means of waves of spontaneous strikes. Arendt refers to the republican character of the Soviets. That is, there was an ideal of founding a republic based on the organizational structure of the Soviets, translated into spaces of freedom. The movement of the Soviets and the Bolshevik Party culminated in the seizure of power. The course taken by Lenin's government opened precedents for further development when the Party, with all its machinery, would become omnipotent. With Stalin's rise to power, total dominance was established. That is, totalitarianism has reached its climax with the persecution and destruction of those who were considered objective enemies and with the creation of concentration camps. With the rise of Nikita Khrushchev to power, some signs of detotalisation of the Soviet Union began.

Keywords: Centenary; freedom; revolution; Soviets.

\section{REFERÊNCIAS}

ARENDT, Hannah. Origens do Totalitarismo. Trad. Roberto Raposo. São Paulo: Companhia das Letras, 1989.

. Entre o Passado e o Futuro. Trad. Mauro W. Barbosa de Almeida. São Paulo: Perspectiva, 1992. 
A Dignidade da Política: ensaios e conferências. Trad. Helena Martins Frida Coelho, Antonio Abranches, César Almeida, Cláudia Drucker e Fernando Rodrigues. Rio de Janeiro: Relume-Dumará, 1993.

. Crises da República. Tradução José Wolkmann. São Paulo: Perspectiva, 2004.

. A Condição Humana. Tradução Roberto Raposo. Revisão técnica Adriano Correia. Rio de janeiro: Forense Universitária, 2010.

. Sobre a Revolução. Trad. Denise Bottmann. São Paulo: Companhia das Letras, 2011.

BOBBIO, Norberto; MATEUCCI, Nicola; PASQUINO, Gianfranco. Dicionário de Política. Brasília: Ed. da UnB, 2010.

LEFORT, Claude. A invenção democrática: os limites da dominação totalitária. Belo Horizonte: Autêntica, 2011. 